\title{
Juvenile Delinquency in Romania: The Indirect Result of the Transition Process
}

\author{
Andrea Fabian
}

W

hen we try to discover the problems associated with juvenile delinquency should be very attentive towards the social, demographic, economical, and political situation of a certain society. Without these issues we would not be able to draw a real picture about the considered phenomenon, neither related to its qualitative, nor related to its quantitative evolution. In the same time represents an absolute necessity to consider the psychological factors of juvenile delinquency, as far as there are both social and psychological aspects involved into the phenomenon. ${ }^{1}$ Meanwhile is not less interesting how a society perceives the phenomenon and what thinks about the causes of juvenile delinquency. The paper follows these directions.

\section{The Geography and Socio-Demography and the Economical and Political Context of Romania}

Romania is situated in the South-Eastern part of Central Europe, with the Carpathian Mountains at the North and the Danube at its Southern border exiting to the Black Sea. Population estimates from 2006 revealed 21.58 million inhabitants, representing a 5.4\% reduction from 1992 .

This population decline corresponded with a decline in fertility and birth rates and an increase in the death rate. In 2006, the female population constituted $51.3 \%$ of the total population and the proportion of the population aged 0-14 years was $15.4 \%$, while those aged 65 years and older represented $14.7 \%$ of the total population. Annual population growth has been negative: $-2.8 / 1000$ inhabitants in 2002, the lowest since 1989. The value remained negative but there was a trend to decrease the size of this negative value. In 2006, the population growth recorded was $-1.8 / 1000$ inhabitants. $^{2}$ The urban population was $55.1 \%$ in 2006.

1 Carey, 1992; Miroiu, 2002; Mitrofan, N., Zdreghea, V., Butoi, T. 1994; Morash, M., Rucker, L. 1989; Brantingham, P.J., Brangtingham, P.L., 1991, Adler, 2000.

2 Ministry of Public Health, 2007a. 
Table 1. Population/demographic indicators, 1948-2006.

\begin{tabular}{lccccccc}
\hline & $\mathbf{1 9 4 8}$ & $\mathbf{1 9 5 6}$ & $\mathbf{1 9 6 6}$ & $\mathbf{1 9 7 7}$ & $\mathbf{1 9 9 2}$ & $\mathbf{2 0 0 2}$ & 2006 \\
\hline Total population (millions) & 15.87 & 17.49 & 19.10 & 21.55 & 22.81 & 21.69 & 22.81 \\
Women (\% of population) & 51.7 & 51.4 & 51.0 & 50.7 & 50.9 & 51.2 & 51.3 \\
$\begin{array}{l}\text { Population aged 0-14 (\% of } \\
\text { total) }\end{array}$ & - & 27.5 & 26.0 & 25.4 & 22.4 & 17.4 & 15.44 \\
$\begin{array}{l}\text { Population aged 65 and above } \\
\text { (\% of total) }\end{array}$ & - & $6.3^{*}$ & $7.9^{*}$ & 9.7 & 11.1 & 14.0 & 14.68 \\
Population density & 66.6 & 73.4 & 80.1 & 90.4 & 95.7 & 90.9 & 90.52 \\
Fertility rate (births per woman) & - & - & - & - & 1.5 & 1.3 & 1.3 \\
Birth rate (per 1000) & 23.9 & 24.2 & 14.3 & 19.6 & 11.4 & 9.7 & 10.2 \\
Death rate (per 1000) & 15.6 & 9.9 & 8.2 & 9.6 & 11.6 & 12.4 & 12.0 \\
\hline
\end{tabular}

Source: National Institute of Statistics, 2006; a Central Directory of Statistics, 1969; Vlădescu, C., et al., 2008.

Table 2. Urban and rural distribution of the population, 1992, 2002, 2004, 2006.

\begin{tabular}{lcccc}
\hline & 1992 & 2002 & 2004 & 2006 \\
& No. $(\%)$ & No. $(\%)$ & No. $(\%)$ & No. $(\%)$ \\
\hline \multirow{2}{*}{ Total } & 22810035 & 21698181 & 21673328 & 21584365 \\
& $(100.0)$ & $(100.0)$ & $(100.0)$ & $(100.0)$ \\
Urban & $12391819(54.3)$ & $11436736(52.7)$ & $11895598(54.9)$ & 11913938 \\
& & & 9777730 & 9670427 \\
Rural & $10418216(45.7)$ & $10261445(47.3)$ & $(45.1)$ & $(44.8)$ \\
\hline
\end{tabular}

Source: National Institute of Statistics, 2007; Vlădescu, C., et al., 2008

Since the revolution of 1989, Romania has gone through a period of rapid and major change in every sector, though the process of economic reform has been gradual rather than radical. Transition has generated an acceleration of poverty, social stratification and exclusion. Most incomes decreased in purchasing power, which has especially injured young families and those with more than one child to raise. $^{3}$ Non-contributory social benefits deteriorated sharply with child allowance reaching its lowest level in 1996 at $28.6 \%$ of its 1989 value. ${ }^{4}$ Various measurements, using different methodologies, indicated the proportion of Romanians living in poverty between $22 \%{ }^{5}$ and $39 \%$ in $1994,{ }^{6}$ compared with about $6 \%$ in $1989 .^{7}$ After the failed stabilization plan of 1997, Romania went through a second deep transitional recession (the first transformation recession was between 1990-1992), but in 2000, a modest economic recovery was seen and after 2004 we could see an economy recovery. Unemployment is concentrated in urban areas: $8.9 \%$ (rural

\footnotetext{
3 Ehrke, M., 2004.

4 Giles, 2002, 204.

5 World Bank.

6 C. Zamfir, 1995, Milanovic, 1995.

7 Giles, 2002.
} 
Table 3. Unemployment rate 1996-2005.

\begin{tabular}{lcccccccccc}
\hline & $\mathbf{1 9 9 6}$ & $\mathbf{1 9 9 7}$ & $\mathbf{1 9 9 8}$ & $\mathbf{1 9 9 9}$ & $\mathbf{2 0 0 0}$ & $\mathbf{2 0 0 1}$ & $\mathbf{2 0 0 2}$ & $\mathbf{2 0 0 3}$ & $\mathbf{2 0 0 4}$ & $\mathbf{2 0 0 5}$ \\
\hline Total (\%) & 6.6 & 8.9 & 10.4 & 11.8 & 10.5 & 8.8 & 8.4 & 7.4 & 6.3 & 7.2 \\
$\begin{array}{l}\text { Of wich } \\
\text { woman (\%) }\end{array}$ & 7.5 & 9.3 & 10.4 & 11.6 & 10.1 & 8.4 & 7.8 & 6.8 & 5.6 & 6.4 \\
\hline
\end{tabular}

Source: National Institute of Statistics, 2007; Vlădescu, C., et al., 2008

$4.3 \%)$. However, it is important to note that the measurement of employment may be inaccurate to some extent.

Following the dramatic collapse of the economy and slow recovery during the transition period, social disparities and wealth inequalities increased rapidly. According to the constitution approved by referendum in December 1991, Romania is a republic in which the rule of law prevails in a social and democratic state with separation of powers. The constitution also guarantees private property rights and a market economy. Romania experienced significant political transformations after 1989, changing from the monopoly of a single party to a diversity of political parties. Romania is a member of the United Nations, the Council of Europe, the World Trade Organization, NATO and, since 1 January 2007, the EU. The Government of Romania has ratified a range of international human rights treaties recognizing the right to health and other health-related rights, including the:

- the Convention on the Rights of the Child (CRC). It has also ratified regional human rights treaties including:

- the Council of Europe Convention for the Protection of Human Rights and Fundamental Freedoms and its Protocols,

- the European Convention for the Prevention of Torture and Inhuman or Degrading Treatment or Punishment, etc. 8

The transition from a centralized system to a democratic one and to the market economy in Romania entailed a lot of social problems. The economic decline, enterprises restructuring, unemployment, widening disparities in different domains, sharpening of external migration, etc., had unfavorable consequences on family lives and, not in the least, on children condition. The sharpest impact was on the families with more children, who faced great difficulties in assuring subsistence means, in children growing up and education. This generated family and school abandon trends, which represent major causes for the proliferation of certain phenomena, such as "institutionalized children" and "children of the streets" and, implicitly, for the amplification of pre-delinquency and juvenile delinquency trends.

8. Vlădescu, C., et al. 2008. 
Table 4. The age of criminal responsibilities in different countries

\begin{tabular}{|c|c|}
\hline $\begin{array}{l}\text { The age of criminal } \\
\text { responsibility }\end{array}$ & Country \\
\hline 10 & England, France, Wales \\
\hline 12 & $\begin{array}{l}\text { Cyprus, Greece, Scotland, the Netherlands, Ireland (until 2006, the age } \\
\text { of criminal responsibility was } 7(!) \text { ) }\end{array}$ \\
\hline 14 & $\begin{array}{l}\text { Austria, Bulgaria, Estonia, Germany, Hungary, Italy, Latvia, Lithuania, } \\
\text { Slovenia and Spain, Czech Republic (from } 15 \text { to } 14 \text { in 2005), Romania }\end{array}$ \\
\hline 15 & Denmark, Finland, Italy, Slovakia and Sweden \\
\hline 16 & Belgium, Luxembourg, Poland and Portugal \\
\hline
\end{tabular}

Source: Panduru, F., Pisică, S., Molnar,M., Poenaru, M., Children in conflict with the law in Romania, MONEE Country Analytical Report, November 2006

Psychologists object that imposing harsher punishments on young criminals will not solve much unless societal roots of this problem are addressed. In order to the Romanian Law, the underage child who did not turn 14 is not criminally liable; the underage child between 14 and 16 is criminally liable, only if it is proved that he committed the crime with power of judgment, but the underage child who has turned 16 is criminally liable.

For assessing the rate and particularity of juvenile delinquency in Romania after 1989 (the post revolutionary period), we used data from:

- Police General Inspectorate,

- National Committee for Statistics,

- Ministry of Justice,

- The Direction for Social Reinstate and Supervision,

- Forensic Medicine from Cluj-Napoca,

- National Raports,

- International Raports.

During 1989-2003, 237.259 minor delinquents have been identified, which means an annual average of 16.947 minor delinquents identified. The biggest number of minor delinquents has been registered in 1998, when 27.382 minor delinquents have been identified. After 1998 the number of minor delinquents has lowered reaching to 15.670 in 2002 and 13.961 in 2003.

The specific crime rate of juveniles between 14 and 17 years (as ratio between the numbers of crimes committed by persons belonging to this age group and the population of the respective group, on July 1st) is very high and significantly higher than the crime rate calculated for total population.

The evolution over time shows that after a decrease between 2000 and 2004, there was an increase in 2005, under the conditions where total crime rate fell from 1.577 cases per 100,000 inhabitants in 2000, to 963 cases in 2005. 
Figure 1. Persons investigated according to their ages (1990-2003)

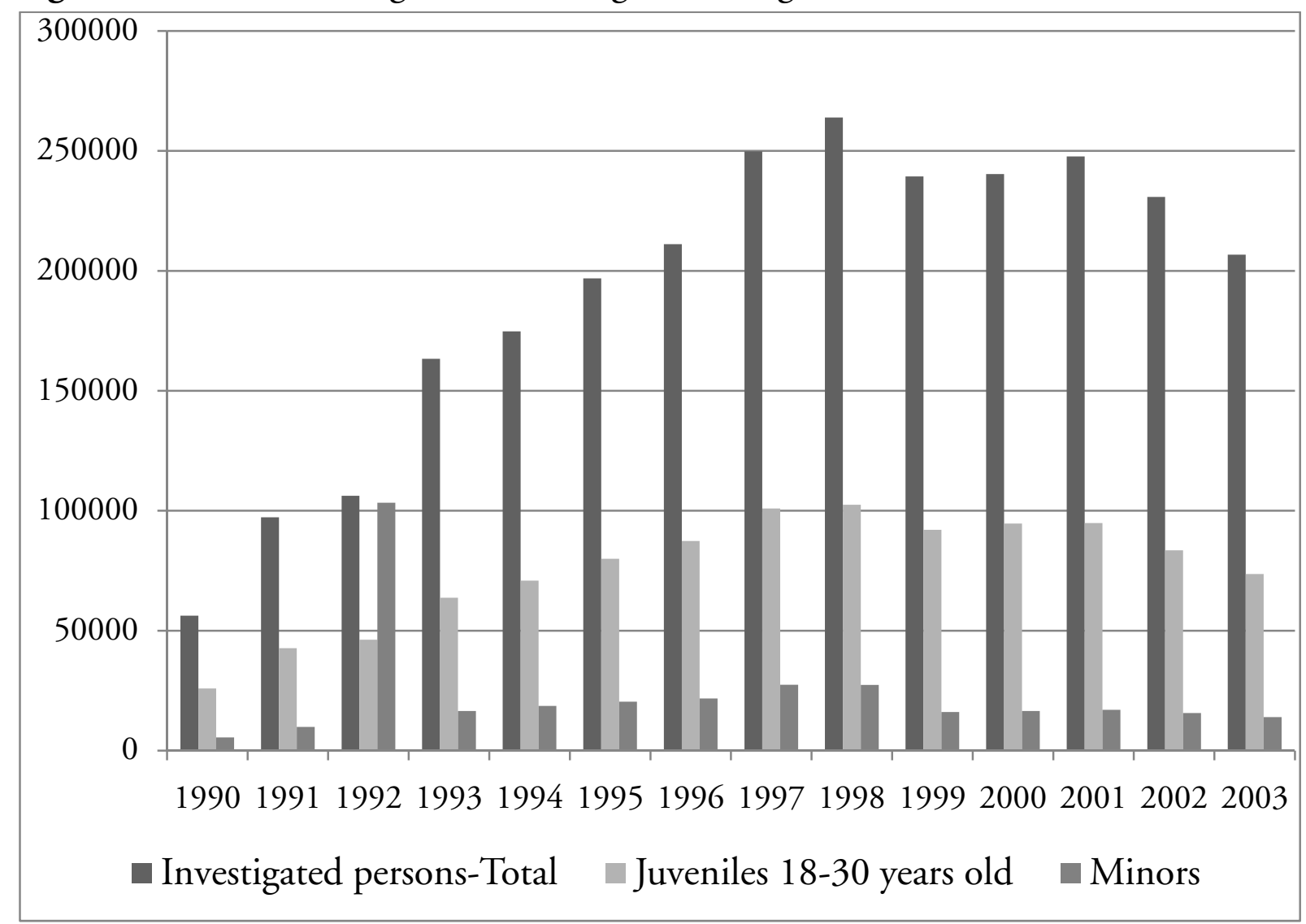

Source: Figure 1-4 were made by the author based on the results of the applied statistical tests on the data from Anuarul Statistic al României (Romanian Statistical Yearbook) 1990-2005, Chapter $18,18.2,18.3,18.4,18.5,18.9$.

Table 5. Number of crimes committed by and with the participation of juvenile offenders 2000-2005.

\begin{tabular}{lcccccc}
\hline & 2000 & 2001 & 2002 & 2003 & 2004 & 2005 \\
\hline Total & 353745 & 340414 & 312204 & 276841 & 231637 & 208239 \\
In ages 14-17 years & 25470 & 23511 & 21460 & 19167 & 18826 & 18578 \\
Weight in total crimes, \% & 7.2 & 6.9 & 6.9 & 6.9 & 8.1 & 8.9 \\
\hline
\end{tabular}

Source: Panduru, F., Pisică, S., Molnar,M., Poenaru, M., Children in conflict with the law in Romania, MONEE Country Analytical Report, November 2006, p.14.

Table 6. Total and juvenile crime rates 2000-2005.

\begin{tabular}{lcccccc}
\hline & 2000 & 2001 & 2002 & 2003 & 2004 & 2005 \\
\hline $\begin{array}{l}\text { Total crime rate } \\
\text { Specific crime rate for children }\end{array}$ & 1.577 & 1.519 & 1.432 & 1.274 & 1.069 & 963 \\
between 14-17 years & 1985.7 & 1745.9 & 1542.6 & 1380.1 & 1345.6 & 1444.0 \\
\hline
\end{tabular}

'per 100000 inhabitants; ${ }^{2}$ per 100000 persons aged 14-17 years (on July $1^{\text {st) }}$ )

Source: Panduru, F., Pisică, S., Molnar,M., Poenaru, M., Children in conflict with the law in Romania, MONEE Country Analytical Report, November 2006, p.15.

Most of the crimes committed by children belong to the category against the patrimony (property): theft, robbery, destroys, etc., which held a weight around $70 \%$ of total infringements committed by children. However, during last years, an 
7. Number and distribution of crimes committed by or with the children's participation (0-17 years), by main categories, 2000-2005.

\begin{tabular}{|c|c|c|c|c|c|c|c|c|}
\hline \multirow{4}{*}{ Year } & \multicolumn{5}{|c|}{ Number } & \multirow{2}{*}{\multicolumn{3}{|c|}{$\begin{array}{l}\text { Distribution } \\
(\text { total }=100.0)\end{array}$}} \\
\hline & \multirow{3}{*}{ Total } & \multicolumn{4}{|c|}{ Of wich } & & & \\
\hline & & \multicolumn{2}{|c|}{ Against persons } & \multirow{2}{*}{$\begin{array}{c}\text { Against } \\
\text { patrimony }\end{array}$} & \multirow{2}{*}{ Others } & \multirow{2}{*}{$\begin{array}{l}\text { Against } \\
\text { persons }\end{array}$} & \multirow{2}{*}{$\begin{array}{c}\text { Against } \\
\text { patrimony }\end{array}$} & \multirow[t]{2}{*}{ Others } \\
\hline & & Total & $\begin{array}{l}\text { Of which, } \\
\text { homicides }\end{array}$ & & & & & \\
\hline 2000 & 26.170 & 957 & 29 & 20.052 & 5.161 & 3.7 & 76.6 & 19.7 \\
\hline 2001 & 24.289 & 1.033 & 28 & 18.144 & 5.112 & 4.3 & 74.7 & 21.0 \\
\hline 2002 & 22.135 & 983 & 33 & 13.144 & 5.008 & 4.5 & 72.9 & 22.6 \\
\hline 2003 & 19.801 & 878 & 36 & 14.394 & 4.529 & 4.4 & 72.7 & 22.9 \\
\hline 2004 & 19.732 & 1.157 & 36 & 13.892 & 4.683 & 5.9 & 70.4 & 23.7 \\
\hline 2005 & 19.728 & 1.454 & 32 & 13.24 & 4.850 & 7.4 & 68.0 & 24.6 \\
\hline
\end{tabular}

Source: Panduru, F., Pisică, S., Molnar,M., Poenaru, M., Children in conflict with the law in Romania, MONEE Country Analytical Report, November 2006, p.15

increase in the number of crimes against the person was recorded (as well as of their weight in total crimes committed by children), particularly for those related to sexual life. In 2005, as compared to 2003, the number of crimes against persons rose by $65 \%$.

Two categories of special protection measures are stipulated by law for children who have penal responsibility: punishments and educative measures.

The number of irrevocably convicted juveniles oscillated during 1990-2003 between 1983 persons in 1990, to 6738 persons in 2000, to 7005 persons in 2002 (when the highest level was recorded) and to 6820 in 2003.

Most of irrevocably convicted juveniles (81 - 85\% during 2000-2005), were convicted for crimes against patrimony, a fact which is linked, among others, to the precarious economic situation of many families with children from Romania.

The types of sentences applied to irrevocably convicted juveniles were changed in terms of structure - beginning with 1999. The most obvious change refers to the fact that the number of persons convicted to imprisonment significantly fell.

During 2000-2004, the total number of those sanctioned with educative measures (in case of children who not reach 16 years of age) significantly decreased (with 794 children, respectively about 40\%), while an increase with 1.495 persons was recorded in 2005. 
Figure 2. Irrevocably convicted minors between 1980-2003



The convictions for crimes against persons hold a weight of about $9-11 \%$ of total, thus drawing the attention on the danger of violent behaviors juveniles.

Table 8. Distribution of irrevocably convicted juveniles, by type of crime (\%), 2000-2005.

\begin{tabular}{lcccccc}
\hline & 2000 & 2001 & 2002 & 2003 & 2004 & 2005 \\
\hline Total persons & 6.738 & 67.26 & 7.005 & 6.820 & 6.341 & 6.796 \\
Out of which (in \%) & & & & & & \\
- against persons & 8.8 & 8.9 & 9.1 & 11.3 & 10.8 & 9.3 \\
- against patrimony & 84.6 & 83.4 & 83.1 & 81.0 & 81.4 & 83.8 \\
- others & 6.6 & 7.7 & 7.8 & 7.7 & 7.8 & 6.9 \\
\hline
\end{tabular}

Source: Panduru, F., Pisică, S., Molnar,M., Poenaru, M., Children in conflict with the law in Romania, MONEE Country Analytical Report, November 2006, p.15.

The rate of irrevocably convictions for juveniles - all punishment types, per 100,000 persons aged $0-17$ years, had an oscillatory evolution, from 133.4 in 2000, to 154.3 in 2005 , recording much lower values as compared to irrevocably convictions rate for the population as a whole. On the contrary, the rate of irrevocably convictions specific to underage persons of 14-17 years recorded higher vales as compared to the one for total population.

During $2000-2005$, the weight of juveniles convicted to freedom deprivation punishments in the total number of underage persons irrevocably convicted decreased. The decrease of this weight was significant for those aged between 16 and 17 years, from $68.1 \%$ in 2000 to $35.1 \%$ in 2004 and 2005. As for those aged 
Irrevocably convicted juveniles, by punishment type, 1990-2003.

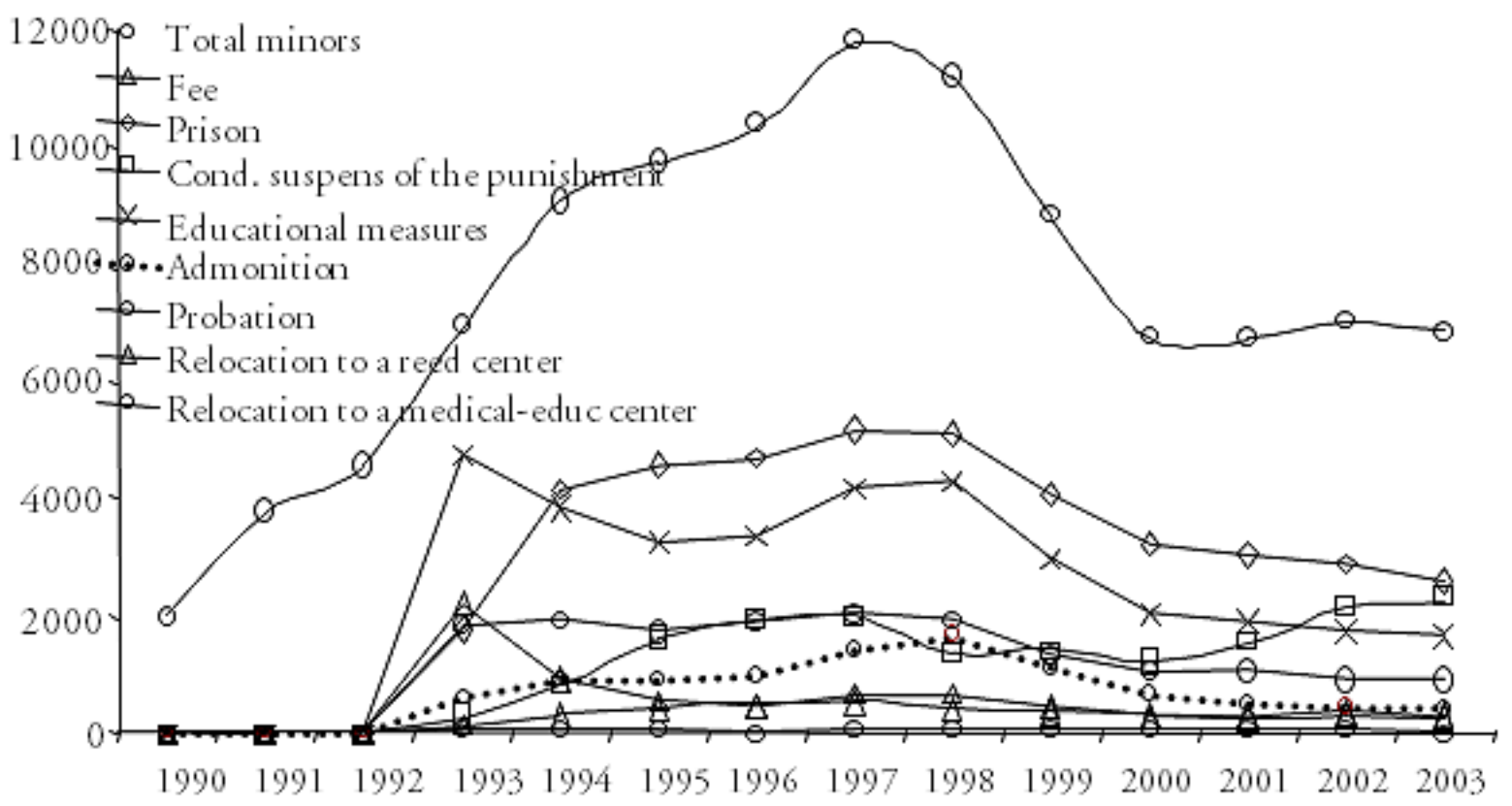
2005.

9. Rate of irrevocably convictions, by main types of punishments, 2000-

\begin{tabular}{|c|c|c|c|c|c|c|}
\hline & 2000 & 2001 & 2002 & 2003 & 2004 & 2005 \\
\hline \multicolumn{7}{|l|}{ Romania } \\
\hline Total & 336.0 & 370.0 & 375.0 & 353.0 & 320.0 & 304.0 \\
\hline - punitive punishments ${ }^{1}$ & 224.0 & 275.9 & 287.9 & 280.0 & 262.2 & 248.8 \\
\hline - imprisonment & 167.9 & 150.6 & 149.2 & 142.3 & 117.3 & 104.8 \\
\hline \multicolumn{7}{|l|}{ Rates for juveniles $^{2}$} \\
\hline Total & 133.4 & 135.5 & 145.4 & 145.7 & 139.1 & 154.3 \\
\hline - punitive punishments ${ }^{1}$ & 87.7 & 92.1 & 103.6 & 104.0 & 94.6 & 101.5 \\
\hline - imprisonment & 63.6 & 61.4 & 59.6 & 55.0 & 39.4 & 42.2 \\
\hline \multicolumn{7}{|l|}{ Specific rates for juveniles ${ }^{3}$} \\
\hline Total & 525.3 & 499.5 & 503.5 & 491.1 & 453.2 & 528.2 \\
\hline - punitive punishments ${ }^{1}$ & 345.1 & 399.7 & 359.0 & 350.4 & 308.1 & 347.7 \\
\hline - imprisonment & 250.3 & 226.5 & 206.6 & 185.6 & 128.2 & 144.6 \\
\hline
\end{tabular}

${ }^{1}$ Refer to: imprisonment, conditional reprieve, reprieve of punishment under supervision; ${ }^{2}$ per 100000 persons of $0-17$ years; ${ }^{3}$ per 100000 persons of $14-17$ years. The population number for indicators computation represents the population on July $1^{\text {st }}$

Source: Panduru, F., Pisică, S., Molnar,M., Poenaru, M., Children in conflict with the law in Romania, MONEE Country Analytical Report, November 2006, p.19. 
Table 10. Number of children for whom educative measures were applied, by type of punishment , 2000-2005

\begin{tabular}{|c|c|c|c|c|c|c|}
\hline & 2000 & 2001 & 2002 & 2003 & 2004 & 2005 \\
\hline Total, Of wich: & 2.023 & 1.880 & 1.722 & 1.639 & 1.229 & 1.495 \\
\hline - reproof & 684 & 512 & 452 & 466 & 453 & 491 \\
\hline $\begin{array}{l}\text { - freedom under supervi- } \\
\text { sion }\end{array}$ & 1,019 & 1,058 & 886 & 914 & 537 & 702 \\
\hline $\begin{array}{l}\text { - internment in a refor- } \\
\text { matory centre }\end{array}$ & 291 & 277 & 361 & 247 & 135 & 298 \\
\hline $\begin{array}{l}\text { - internment in a medi- } \\
\text { cal-educative centre }\end{array}$ & 29 & 33 & 23 & 12 & 4 & 4 \\
\hline
\end{tabular}

Source: Panduru, F., Pisică, S., Molnar, M., Poenaru, M., Children in conflict with the law in Romania, MONEE Country Analytical Report, November 2006, p.19

Figure 4. Weight of juveniles convicted to freedom deprivation punishments in total number of irrevocably convicted juveniles, by age group (\%), 2000-2005.

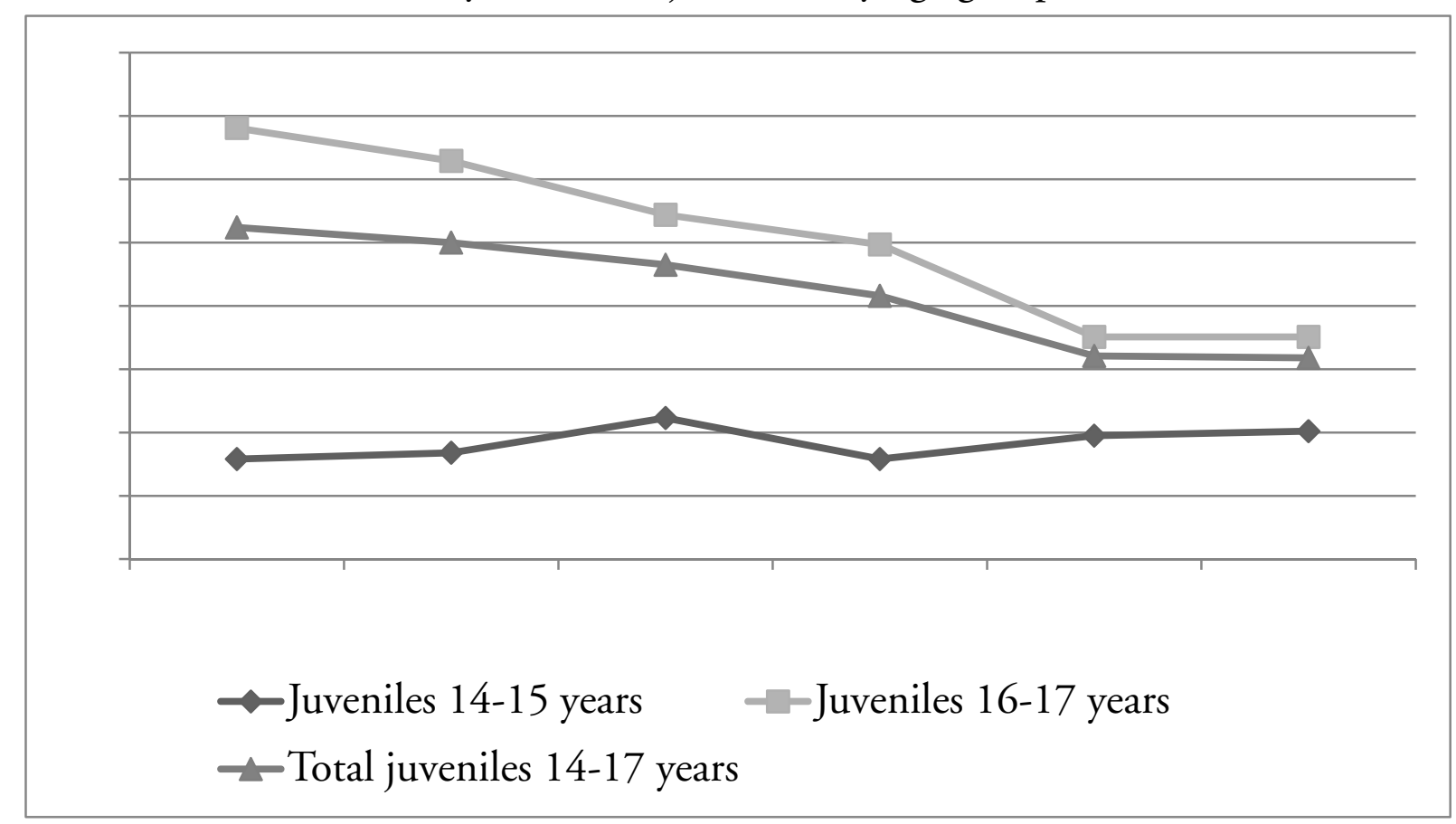

Source: Panduru, F., Pisică, S., Molnar,M., Poenaru, M., Children in conflict with the law in Romania, MONEE Country Analytical Report, November 2006, p.19.

between 14 and 15 years, this weight oscillated over time, at present being around $20 \%$.

For children in conflict with law and having penal liability, in Romania, exists three types of correctional facilities: reformatory centres for underage persons (RCU); penitentiaries for underage persons and youth (PUY); sections within penitentiaries for adults (within most of the penitentiaries for adults sections for underage persons exist, for most of them the trials being ongoing, who are to be afterwards transferred to a RCU or PUY).

$9 \quad$ Panduru et al. 2006. 
Juveniles in reformatory institutions, at the end of the year, 2000-2005.

\begin{tabular}{|c|c|c|c|c|c|c|}
\hline & 937 & 735 & 743 & 655 & 570 & 593 \\
\hline $\begin{array}{l}\text { - in residential reformatory } \\
\text { schools (RCU) }\end{array}$ & 359 & 279 & 238 & 185 & 170 & 261 \\
\hline - in penitenciaries & 578 & 456 & 508 & 470 & 353 & 332 \\
\hline
\end{tabular}

Panduru, F., Pisică, S., Molnar, M., Poenaru, M., Children in conflict with the law in Romania, MONEE Country Analytical Report, November 2006, p.23

The total number of juveniles placed in reformatory institutions (at the end of the year) decreased from 2000 to 2004, from 937 persons to 570 persons, slightly increasing in 2005 as compared to previous year, to 593 persons.

During 2000 - 2005, the sharpest decrease was recorded for those from penitentiaries (246 persons, respectively over $40 \%$ ). A significant decrease was also noticed for those from residential reformatory schools, from 359 to 170 in 2004, afterwards increasing to 261 in the next year (by 53\% as compared to previous year).

\section{Psychological particularities of juvenile delinquents}

It is very important to underline the importance of psychological processes for youth ending up in delinquent behavior. In the transition period the society was characterized by less inner control and less outer control. In such conditions it was obvious that we will find some psychological particularities on delinquent's behavior.

The presentation is based on an extensive study of 420 prisoners from Gherla Extreme Safety Prison and External Section from Cluj-Napoca (210 of them are between 14-18 years old and 210 are between 19-21) chosen at random and other 420 persons from the control group (half of them between 14-18 and half between 19-21) chosen by the methods of pattern stratification, who were tested with the following psychological tests:

1. Nowicki \& Strickland's Internal-External Control Scale for Children

2. McGuire \& Priestley's Testing Your Reaction,

3. Zuckerman-Kuhlman's Personality Questionnaire ${ }^{10}$

The results were compared with previous research data on Romanian population. In case of the psychological factors we used $t$ test to check if there is any differences between the two groups (see table 12).

10 Kurko-Fabian, 2006, Fabian, 2007. 
Differences between the delinquent and control group regarding the psychological factors.

\begin{tabular}{lccccc}
\hline Psychological factor & Delinquent & Average & t-value & Df & Significance \\
\hline \multirow{2}{*}{ Self control } & Yes & 17.28 & 19.03 & 838 & 0.000 \\
& No & 12.33 & & & \\
Impulsivity & Yes & 19.17 & 7.22 & 838 & 0.000 \\
\multirow{2}{*}{ Sensation seeking } & No & 15.93 & & & \\
\multirow{2}{*}{ Sociability } & Yes & 9.62 & 19.00 & 838 & 0.000 \\
Activity & No & 5.87 & & & \\
\hline
\end{tabular}

Source: This and the following table were made by the author using statistical methods on data from the following source: Police General Inspectorate and Forensic Medicine from Cluj-Napoca

Table 13. Psychological factors, a measure of delinquency related to the number of committed crimes (standardized regression coefficients, significance). Dependent variable: the number of committed crimes.

\begin{tabular}{|c|c|c|}
\hline Independent variable & Beta coefficients & Significance \\
\hline Type of self control & 0.164 & 0.001 \\
\hline Sensation seeking & 0.151 & 0.003 \\
\hline Sociabilty & 0.108 & 0.022 \\
\hline $\mathrm{R}$ square $(\%)$ & & \\
\hline
\end{tabular}

From the above table turns out that: The value of self control is much higher in case of delinquents than in case of the other group (value t: 19.03 at 0.000 significance). Juvenile delinquents are more impulsive than non-delinquents (value $t$ : 7.22, significance: 0.000 ). There is a difference at the delinquents' advantage concerning the sensation seeking (value t: 19.00 , at 0.000 significance). We can say that juvenile delinquents have more pronounced desire for sensation seeking. Delinquents are more active than their non-delinquents mates (value t: 6.40, significance: 0.000 ); they are less sociable (value t: -2.53 , significance: 0.011 ) than nondelinquent mates, but the more sociable a delinquent is, the more he commits crimes (value Beta: 0.108, significance: 0.022) (see table 13).

As we already said, the transition period was characterized by less inner control and less outer control. We can see its effects on delinquent's behavior: in lack of other possibilities, they live their desire for sensation seeking in criminal acts; of course their high score of impulsivity and activity consolidate this antisocial behavior.

These results confirm the fact that there are significant differences from the psychological point of view between juvenile delinquents and non-delinquents. 


\section{Romanian Public Views on Juvenile Crime and Punishment}

According to the results of a pilot study made in 2003 in Bucharest, the capital of Romania (on 295 respondents aged 18 and over) there is a mismatch between the "real" juvenile crime trend and the public's perception of that "reality": ${ }^{11}$

1. the majority of respondents $(75.9 \%)$ believed that juvenile crime was on the increase (as official crime statistics show that juvenile crime declined over the period in question),

2. the overwhelming majority of respondents (91.5\%) also substantially overestimated the extent to which juvenile crime involves violence, while underestimating the proportion of crimes involving theft (67.2\%) (statistics available at the time of conducting the research12 show that the vast majority $(83 \%)$ of juveniles convicted in 2001 were involved in acquisitive crimes (mainly theft) and only $8.8 \%$ were convicted for violent crimes).

There are a number of possible reasons why people's estimations of crime and sentencing figures are so wide of the mark. ${ }^{12}$

1. official crime statistics are inaccessible to the public and often out of date, lack of knowledge is therefore hardly surprising,

2. secondly, as the media are the main source of information, public attitudes are subject to influence by unrepresentative reporting,

3. discrepancies between national and local crime rates could induce differences of opinions.

Interestingly, Chi-square tests indicate that respondents' level of knowledge about some aspects of juvenile crime differed according to socio-demographic variables: ${ }^{13}$

- Poorer (low income or no income) respondents were more likely to overestimate the proportion of juvenile offenders engaged in violent crimes;

- Younger respondents tended to overestimate imprisonment rates for juvenile offenders;

- The elderly underestimated the imprisonment rates for juvenile offenders who had committed theft and burglary.

- About the role that sentencing has in preventing crime, almost two thirds of the sample $(63.6 \%)$ believed that sentencing was one of the major factors in preventing crime.

11 Haines, 2007.

12 Ibid., 2007.

13 Ibid., 2007 
- Prison was not ranked highly as a first option for reducing juvenile crime $(2.4 \%)$, nor were more police on the beat $(0.6 \%)$. By far the most common response to this question was better parenting (48.1\%), followed by better discipline in schools (33.8\%) and more positive leisure opportunities for young people $(20.5 \%)$. There was also support for greater use of non custodial sentences, such as community service and probation (see table 14).

Table 14. Best Strategies for Juvenile Crime Prevention

\begin{tabular}{lc} 
The first most effecrive juvenile crime prevention measure & $\%$ \\
\hline Improve discipline in the family & 48.1 \\
Increase severity of sentencing & 14.7 \\
Increase the offer for jobs/opportunities for work & 14.7 \\
Improve discipline in schools & 8.9 \\
Increase positive leasure opportunities for young people & 5.1 \\
Increase use of community sentences like probation & 3.8 \\
Increase use of imprisonment & 2.4 \\
Increase use of community sentences like community service & 1.7 \\
Increase numbers of police officers & 0.6 \\
Other measures & -
\end{tabular}

Source: Haines, A. (2007): Juvenile crime and punishment in Bucharest, Romania: A Public Opinian Survey In. Internet Journal of Criminology

\section{General Conclusions About the Juvenile Ddelinquency as the Indirect Result of the Transition Process}

The communist period was characterized by poverty, meanwhile, mostly after 1990 new possibilities have appeared. Thus, a Mertonian situation occurred, which meant that albeit there were clear goals and targets, the legitimate instruments for their achievements were missing. Given this missing link, a category of the population made use of illegitimate instruments for goal-achievements. Such people enriched the lines of the delinquents.

Another important factor is represented by social mobility. Due to the modernization process, many rural inhabitants have migrated to cities. This horizontal mobility meant in many of the cases, the impossibility of social integration, the sentiment of rootless, and the missing link between the goals and instruments for their achievement. These facts resulted also in delinquency. Many youngsters with rural origin became urban delinquents. The results of our research show the fact that the preferred area of minor delinquents is the city (the number of crimes committed by minors in 1990 was 43.426 in urban area, and 20.571 in rural area and in 2000 was 224.236 in urban area, and 129.135 in rural area) from the total crime, because represents a space that besides opportunities offers them anonymity. 
The city is a favorable place for the formation of delinquent gangs. Young people who are not supervised neither by their family, nor by the community in which they live, those who abandon the school and spend the most of their time on the streets, and lack any other form of occupation are attracted by the opportunities of this way of life.

Our research results confirm the fact that there are significant differences from the psychological point of view between juvenile delinquents and non-delinquents (they have much higher value of self control (value t: 19.03 at 0.000 significance), they are more impulsive (value t: 7.22 , significance: 0.000 ), they are more characterized by sensation seeking (value t: 19.00 , at 0.000 significance), they are more active (value t: 6.40, significance: 0.000 ) and they are less sociable (value t: -2.53 , significance: 0.011 ) than their non-delinquents mates.

About the public opinion regarding the juvenile crime and punishment it would be wrong to characterize the Romanian public as being highly punitive in respect to juvenile crime and sentencing. In contrast to judicial practice in Romania, there is public support for community based sentencing alternatives for juvenile offenders, especially those committing minor offences. The public do not have a great deal of confidence in the ability of the courts to prevent crime. They believe that preventing juvenile crime is more a question of changing the family and school environment and increasing the chances of gaining employment and providing opportunities for young people to spend their spare time positively, rather than stressing more imprisonment or police on the beat. However, this does not mean the public see no role for sentencing in preventing crime. ${ }^{14}$

In conclusion we can say that the communist regime as a totalitarian and repressive system has inhibited criminality. During the transitional period laws were ignored, the population was not afraid from the police which loose its dignity due to the illegitimate acts of the former, communist 'militia'.

Democracy is vulnerable because is permissive regarding individual freedom. The direct consequence of this wrongly interpreted freedom was the rising tendency in criminality.

Andrea Fabian is Associate Professor at the Department of Social Work, BabesBolyai University, Cluj, Romania.

14 Ibid., 2007. 


\section{References}

Adler, F., Mueller, G. O. W., Laufer, W. S. Krimonológia (Budapest, Osiris, 2000). Brantingham, P. J., Brangtingham, P.L. Introduction: The Dimension of Crime in Enviromental Criminology. Brantingham and Brangtingham (coord.), (Prospect Heights, Ill, Waveland, 1991).pg. 8.

Carey, G. Twin Imitation for Antisocial Behavior: Implications for Genetic Environment Research. In: Journal of Abnormal Psychology. 101 (1992), pg. $18-25$.

Ehrke, M. Economia, politica şi societatea în capitalismul postcomunist. (2004), http://www.sar.org.ro/PWR-9-1-ro.pdf.

Fabian, A. Aspecte teoretice şi statistice ale devianței şi delincvenței juvenile (ClujNapoca, Echinox, 2007).

Haines, A. Juvenile crime and punishment in Bucharest, Romania: A Public Opinian Survey in Internet Journal of Criminology (2007).

Kurkó-Fabian, A. Delincvența juvenilă în România după 1989. (Cluj-Napoca, Studia, 2006).

McGuire, J., Priestley, P. Offending Behaviour. Skills and Stratagems for Going Straight (London, 1993). pp. 152-181.

Miroiu, M. Convenio (Iaşi, Polirom, 2002), pg. 120-127.

Mitrofan, N., Zdreghea, V., Butoi, T. Psihologie judiciară. (Bucureşti, Şansa SRL, (1994).

Morash, M., Rucker, L. Deviance. The Intreactionist Perspective. (New York, Macmillan, 1989).

Nowicki, Strickland A locus of control scale for children in Robinson, John P.; Shaver, Phillip R.; Wrightsman, Lawrence S. eds. Measures of Personality and Social Psychological Attitudes. San Diego. California, (1991), pp. 442-446.

Panduru, F., Pisică, S., Molnar,M., Poenaru, M. Children in conflict with the law in Romania, MONEE Country Analytical Report, November 2006.

Vlădescu, C., Scîntee, G., Olsavszky, V.: Romania Health system review, Health Systems in Transition Vol. 10 No. 3 2008:1. (WHO).

Zuckerman, M. Dimension of sensation seeking. In Journal of Consulting and Clinical Psychology. 36 (1971), pp. 45-52.

\section{Official statistics}

Central Directory of Statistics, 1969.

Comisia Naţională pentru Statistică, (1990-2004), Anuarul statistic al României.

Direcția de Cazier şi Evidență Operativă din Inspectoratul General al Poliției Române, Date statistice. 
Inspectoratul General al Poliției din cadrul Ministerului de Interne, Date statistice. Institutul Medico-Legal, Cluj-Napoca (1995-2004), Dosarele inculpaţilor minori.

Ministerul de Interne, Inspectoratul de Poliție al județului Cluj, Serviciul Cazier Judiciar şi Evidența Operativă (1990-2002), Date statistice.

Ministerul Justiţiei, Date statistice.

National Institute of Statistics, 2007.

Poliția Județului Cluj (1990), Date statistice, registre.

Poliția Județului Cluj (1991-1995), Date statistice, registre. 